\title{
About approximation of $B$-continuous functions of several variables by generalized Boolean sum operators of Bernstein type on a simplex
}

\section{IRINA BÂRSAN, PETRU BRAICA and MIRCEA FĂRCAŞ}

\author{
ABSTRACT. \\ The aim of this paper is to study the convergence of the sequence of generalized Boolean sum (GBS) operators $\left(U B_{m}\right)_{m \geq 1}$ for $B$-continuous \\ functions $f \in C_{b}\left(\Delta_{4}\right)$.
}

\author{
SECONDARY SCHOOL "AVRAM IANCU" \\ VICTORIEI 84, 430122 BAIA MARE, ROMANIA \\ E-mail address: barsan.daniela@yahoo.com \\ SECONDARY SCHOOL "Grigore MoISIL" \\ Mileniului 1, 440037 SATU Mare, Romania \\ E-mail address: petrubreyahoo.com \\ National College "Mihai Eminescu" \\ Mihai EMinescu 5, SATU MARE 440014, Romania \\ E-mail address: mirceafarcas2005@yahoo.com
}

